\title{
ANALISIS AKAD PEMBIAYAAN MUDHARABAH DAN IMPLIKASINYA TERHADAP KESEJAHTERAAN ANGGOTA DALAM PERSPEKTIF EKONOMI SYARI'AH \\ (Studi Kasus di Kopwan BMT An Nisa Yogyakarta 2013)
}

\author{
Muhammad Ngasifudin dan Abdul Salam \\ Prodi Ekonomi Syariah Alma Ata Yogyakarta \\ Email: salam.eretan@gmail.com
}

\begin{abstract}
Vision and Mission Suitability Kopwan BMT An-Nisa 'is a good partner for a whole by using the principle of sharing (profit sharing) because of the characteristics common to Kopwan BMT An-Nisa' TOTAL LIABILITY such as mudaraba financing, the bank mechanism Shari'ah applies to products financing-products. The parties involved in this case have to do transparency and partnership are good and relaxed and able to provide a sense of peace to the members. Because all of the expenses and income with business berkitan routine. Financing is in Kopwan BMT An-Nisa 'is constantly increasing, this study to describe bertujaun of financing, the system of financing and results on the impact of the financing is for the welfare of members. In this case study using qualitative research methods with descriptive approach, to obtain data through observation, interviews and documentation, analysis of the data obtained, collected, processed, analyzed and then matched with the concept and application of financing on Kopwan BMT An-Nisa 'interpretation and reviewing pull back later at a conclusion and give suggestions.
\end{abstract}

Keywords: mudaraba financing, profit and lose sharing, welfare (Fallah)

\section{PENDAHULUAN}

Pertumbuhan ekonomi dalam pembangunannya tidaklah terlepas dari peran serta sektor perbankan. Bank pada prinsipnya sebagai lembaga intermediasi, menghimpun dana dari masyarakat yang mengalami surplus dana dan menyalurkan kepada masyarakat yang membutuhkan dana. Sudah bertahun-tahun ekonomi dunia didominasi oleh perbankan dengan sistem bunga, walaupun masih banyak negara yang mengalami kemakmuran dengan sistem ini, akan tetapi masih banyak yang belum bisa mencapai kemakmuran, bahkan semakin terpuruk dengan sistem bunga. Maka pada dasarnya bermunculan bank-bank Islam yang menaungi dengan sistem bagi hasil.

Perbankan Islam adalah aplikasi dari sebuah sistem perekonomian, salah satunya adalah sistem Mudharabah, Tetapi figh (yurisprudensi) atau teori yang membahas tentang perbankan Islam sangat minim dan datang belakangan setelah perbankan Islam berdiri dan beroperasi baru teori itu dikaji, dengan demikian dapat dibayangkan terjadinya teori akomodasi untuk legitimasi sebuah lembaga keuangan syari'ah (Sumitro:1997). Perbankan syari'ah 
tidak hanya semata-mata mencari keuntungan dalam operasionalnya, tetapi terdapat nilai-nilai sosial kemasyrakatan dan spiritualisme yang ingin dicapai, perbedaan mendasar dari perbankan syari' ah dengan perbankan konvensional adalah diharamkannya sistem bunga (Nawawi: 2009). Menurut Syafi'i Antonio profit sharing dipengaruhi oleh investmen rate, jumlah dana tersedia untuk diinvestasikan dan nisbah (Antonio:2001)

Dalam sistem ekonomi Islam, tingkat bunga yang dibayarkan bank kepada nasabahnya digantikan dengan presentase atau porsi bagi hasil, dan tingkat bunga yang diterima oleh bank akan digantikan dengan presentase bagi hasil, dua betuk rasio keuntungan yang dijadikan instrumen untuk memobilisasi tabungan dan disalurkan pada aktivitas-aktivitas bisnis produktif, walaupun rasio bagi hasil ditetapkan lebih dahulu, namun ketika tingkat keuntungan berfluktuasi maka tingkat pendapatannyapun akan berfluktuasi, dengan kata lain pendapatan akan berfluktuasi dan tidak menentu (Muhamad:2009)

Nisbah keuntungan harus dibagi untuk kedua pihak. Salah satu pihak tidak diperkenankan mengambil seluruh keuntungan tanpa membagi kepada pihak yang lain, selain itu proporsi keuntungan masing- masing pihak harus diketahui pada waktu akad dan proporsi tersebut harus dari keuntungan.

Bagaimana Islam membahas tentang keadilan sosial dan kesejahteraan sosial dalam kehidupan umat manusia, bagaimana perwujudan keduanya dalam Islam serta bagaimana peran pekerja sosial, berbicara tentang kesejahteraan dan keadilan maka akan timbul suatu pertanyaan diantaranya keduanya manakah yang harus didahulukan( Lessy: 2007)

Koperasi Wanita Baitul Maal Wa Tamwil (BMT) An-Nisa' (Kopwan BMT An-Nisa') dengan tujuan yang prospektif yang tujuannya untuk meningkatkan kesejahteraan nasabah Kopwan BMT An-nisa ini merupakan salah satu lembaga keuangan alternatif yang berlandaskan hukum Islam yang sesuai dengan visi misinya yakni Kopwan BMT An-Nisa' adalah memberikan solusi bagi anggota dan masyarakat umum dalam bidang perekonomian Menurut laporan Kopwan BMT An-nisa' pada periode tahun 2012 dan tahun 2013 adalah sebagai berikut :

\begin{tabular}{lllc}
\hline Uraian & Tahun 2012 & Tahun 2013 & $\%$ \\
\hline Pendapatan & $16,805,000$ & $25,759,400$ & $21 \%$ \\
Pembiayaan & 221.500 .000 & 377.600 .000 & $26 \%$ \\
Bagi hasil & $12,220,500$ & $17,252,400$ & $17 \%$ \\
\hline
\end{tabular}

Dengan melihat jumlah persentase di atas dari tahun-ketahun mengalami peningkatan yang signifikan, dari hasil wawancara dengan manager pihak Kopwan BMT An-nisa' bahwa pembiayaan mudharabah mampu memberikan semangat untuk lebih giat lagi dalam mendapatkan bagi hasil dengan sesuai dengan akad. Dengan pembiayan mudharabah pada Kopwan BMT An-Nisa' pihak anggota yang tidak mempunyai modal untuk biaya usaha tanpa harus menunggu modal dari sendiri sehingga pihak Kopwan BMT An-Nisa' dapat membantu secara keuangan.

Melihat Fenomena tersebut maka, dapat disimpulkan bahwa pembiayaan mudharabah untuk penyelenggaraan pembiayaan mempunyai masalah yang harus dipecahkan. Untuk itulah peneliti mengangkat judul Analisis Akad Pembiayaan Mudharabah dan Implikasinya Terhadap Kesejahteraan Anggota Dalam Perspektif Ekonomi Syari'ah"

Berdasarkan latar belakang tersebut maka, permasalahan yang dapat diambil dalam penelitian ini adalah: Pertama, Bagaimana praktek pembiayaan

Muhammad

Ngasifudin

Abdul Salam

64

JURNAL EKONOMI SYARIAH INDONESIA, Volume V, No.1 Juni 2015 
Mudharabah di Kopwan BMT An-Nisa'? Kedua, Bagaimana Tinjauan Ekonomi Syari'ah terhadap praktek pembiayaan Mudharabah pada Kopwan BMT An-Nisa'? Ketiga, Bagaimana dampak Pembiayaan Mudharabah terhadap kesejahteraan (falah) nasabahnya?

\section{METODE PENELITIAN}

Dilihat dari segi bentuk data dalam penelitian ada dua jenis data, yaitu data kualitatif dan data kuantitatif (Teguh :2005). Dan data yang digunakan dalam penelitian ini adalah data kualitatif yang datanya diambil dari lapangan, field research. Penelitian dengan pendekatan kualitatif lebih menekankan analisanya pada proses penyimpulan dedukatif dan induktif serta pada analisis terhadap dinamika hubungan antar fenomena yang diamati, dengan menggunakan logika ilmiah (Azwar :2005)

Penelitian kualitatif biasanya digunakan pada penelitian dalam bidang ilmu sosial (Haryono;1995). Penelitian kualitatif sebagai prosedur penelitian yang menghasilkan data deskritif berupa kata-kata tertulis atau lisan dari orang-orang dan perilaku yang dapat diamati (Haryono;1995). Pendekatan ini diarahkan pada latar dan individu tersebut secara utuh (holistic), tidak mengisolasikan individu ke dalam variabel, tetapi perlu memandangnya sebagai bagian dari suatu keutuhan.

Subyek penelitian adalah orang atau apa saja yang bisa menjadi sumber dalam memberikan informasi atau data penelitian. Suharsimi Arikunto membagi sumber penelitian dalam tiga katagori yaitu person, place, dan papaer(Arikunto :2008), Metode penentuan subyek ini bertujuan untuk menentukan siapa saja yang akan menjadi subyek penelitian skripsi ini :

Ketua Kopwan BMT An-Nisa', dengan alasan sebagai obyek penelitian, sebab mengingat bahwa direktur adalah orang yang memimpin perusahaan tersebut sehingga mengetahui bagaimana menjalankan usahanya, dan mengetahui bagaimana menjalankan usahanya, dan staff bagian pembiayaan bagi hasil Mudharabah adalah orang yang paling menguasai dan mengetahui prosedur serta realisasi akad Mudharabah. dalam rangka pembiayaan dengan prinsip bagi hasil.

18 nasabah atau mitra bank sebagai sampel, karena mengingat efesiensi waktu dan biaya, sebab nasabah atau mitra bank tersebut berkedudukan di Yogyakarta dan sekitarnya dengan kreteria nasabah atau mitra bank dijadikan responden merupakan nasabah yang menjadi mitra yang mendapatkan pembiayaan dengan akad Mudharabah di BMT An-Nisa'.

Populasi adalah keseluruhan unit analisis yang karakteristiknya akan diduga, anggota unit populasi disebut elemen populasi(Sumantri:2011). Dalam hal yang sama pendapat lain, populasi adalah keseluruhan subjek penelitian (Mahfoedz:2011), sedangkan menurut Sugiono populasi adalah wilayah generasilisasi yang terdiri atas obyek atau subyek yang mempunyai kualitas dan karakteristik tertentu yang ditetapkan oleh peneliti untuk mempelajari dan kemudian ditarik kesimpulannya. (Sugiono :2001)

Jadi populasi bukan hanya orang, tetapi juga benda-benda alam yang lain. Populasi juga bukan sekedar jumlah yang ada obyek atau subyek yang

Analisis

Akad

65 dipelajari, tetapi meliputi seluruh karakteristik atau sifat yang dimiliki oleh subyek atau obyek itu.(Sugiono :2001) Dalam penelitian populasi yang ada menjadi nasabah Kopwan BMT An-Nisa' adalah 184 Nasabah. Suharsimi Arikunto yaitu: "A pabila subyek penelitian kurang dari 100, lebih baik diambil semua sehingga penelitianya merupakan penelitian populasi, selanjutnya

JURNAL EKONOMI SYARIAH INDONESIA, Volume V, No.1 Juni 2015 
jika jumlah subjek pada penelitian tersebut besar, dapat diambil 10-15\% atau 20-25\% atau bahkan lebih(Arikunto :2008) maka dalam penelitian ini diambil sampel sebanyak 18 nasabah.

Teknik pengambilan sampel yang digunakan penulis dalam penulisan skripsi ini adalah metode pengambilan sampel probabilitas/acak (random sampling), yaitu suatu metode pemilihan ukuran sampel dimana setiap anggota populasi mempunyai peluang yang sama untuk dipilih menjadi anggota sampel.

\section{TEKNIK PENGUMPULAN DATA}

Untuk mendapatkan hasil yang diharapkan agar memperoleh data yang diharapkan, penelitian harus menggunakan metode yang relevan dengan metode yang dibutuhkan. Metode yang dimaksud untuk meninjau dan mengumpulkan data yang berasal dari keterangan subyek, untuk mendapatkan hasil dari beberapa subyek yang telah ditentukan sebelumnya, maka digunakan beberapa metode, diantaranya:

\section{Observasi}

Metode observasi adalah pengamatan, perhatian atau pengawasan, metode pengumpulan data dengan observasi artinya mengumpulkan data atau menjaring data dengan melakukan pengamatan terhadap subyek dan atau obyek penelitian secara seksama cermat dan teliti dan sistematis( Supardi:2005). Dalam menggunakan metode observasi cara yang paling adalah melengkapinya dengan format atau blanko pengamatan sebagai instrumen, dari peneliti berpengalaman diperoleh suatu petunjuk bahwa mencatat data observasi bukanlah sekedar mencatat, tetapi juga mengadakan pertimbangan kemudian mengadakan penelitiankedalamsuatu skala bertingkat

Metode observasi adalah metode yang paling utama dalam penelitian ini. Metode ini digunakan untuk memperoleh data tentang gambaran umum, Oleh karena itu penelitian ini menggunakan metode observasi secara langsung di Kopwan BMT An-Nisa' mengamati dan mencatat secara sistematis fenomenafenomena yang diteliti.

\section{Metode Wawancara (interview)}

Wawancara digunakan sebagai teknik pengumpulan data-data apabila peneliti ingin melakukan studi pendahuluan untuk menemukan permasalahan yang harus diteliti, dan juga apabila peneliti ingin mengetahui hal-hal dari responden yang lebih mendalam dan jumlah respondennya sedikit/ kecil (Sugiono:2009)sutrisnohadi (1986) mengemukakan bahwa anggapan yang perlu dipegang oleh peneliti dalam menggunakan metode interview juga kuisioner (angket) adalah sebagai berikut: a) Bahwa subyek atau responden adalah orang yang paling tahu tentang dirinya sendiri, b) Bahwa apa yang dinyatakan oleh subyek kepada peneliti adalah benar dan dapat dipercaya, c) Bahwa interprestasi subyek tentang pernyatan-pernyatan yang diajukan peneliti kepadanya adalah sama dengan apa yang dimaksud oleh peneliti

Metode ini digunakan untuk mendapatkan jawaban dari responden dengan cara tanya jawab dan suatu komunikasi verbal semacam percakapan yang bertujuan memperoleh informasi. Wawancara yang digunakan adalah wawancara semi terstruktur (semistructured interview). Wawancara model ini memberikan kebebasan kepada peneliti untuk menemukan atau memperoleh

Muhammad

Ngasifudin

Abdul Salam

66

JURNAL EKONOMI SYARIAH INDONESIA, Volume V, No.1 Juni 2015 
informasi secara terbuka. Dalam wawancara ini peneliti perlu mendengarkan dan mencatat infomasi dari informan.

\section{Dokumentasi}

Metode dokumentasi yaitu mencari data mengenai hal-hal atau variabel yang berupa catatan, transkip, buku, surat kabar, majalah, prasasti, notulen rapat, lengger, aggenda dan sebagainnya, dalam menggunakan dokumentasi ini peneliti memegang ceklist untuk mencari variabel yang sudah ditentukan, (Arikunto:2008)

Lokasi penelitian di Kopwan BMT An-Nisa' Jl. Parangtritis No. 10 KM4,3. Dipilihnya Kopwan BMT An-Nisa' dikarenakan Provinsi DIY dan masyarakat Yogyakarta dikenal sebagai masyarakat yang heterogen, beragam budaya, suku, agama maupun kepercayaan, sehingga sudah barang tentu memiliki problematika yang perlu dikaji secara ilmiah dari aspek Ekonomi Syari'ah yang membutuhkan pemahaman bagi perkembangan sebuah Bank yang mendasarkan pada syari'ah dengan prinsip bagi hasil

\section{HASIL DAN PEMBAHASAN}

\section{Gambaran Kopwan BMT An-Nisa'}

\section{Sejarah SingkatBaitul Mal wa Tamwil.}

Setelah berdirinya Bank Muammalat Indonesia timbul peluang untuk mendirikan bank-bank yang berprinsip syari'ah. Operasionalisasi Bank Muamalat Indonesia kurang menjangkau usaha masyarakat kecil dan menengah, maka muncul usaha masyarakat kecil dan menengah, maka muncul seperti BPRS dan BMT yang bertujuan untuk mengatasi hambatan operasionalisasi didaerah.

Disamping itu ditengah-tengah kehidupan masyarakat yang hidup serba berkecukupan muncul kekawatiran akan timbulnya pengikisan akidah. Pengikisan akidah ini bukan hanya dipengaruhi dari aspek syiar Islam tetapi juga dipengaruhi oleh lemahnya ekonomi masyarakt, sebagaimana diriwayatkan oleh Rasullulah SAW " kefakiran itu mendekati kekufuran" maka keberadan BMT diharapkan mampu mengatasi maasalah ini lewat pemenuhan kebutuhan-kebutuhan ekonomi masyarakat.(Sudarsono:2008)

Sejarah KOPWAN BMT An-Nisa'.

Letak geografis Kopwan BMT An-Nisa' yang terletak di Jalan Parangtritis Km.4,3 No 10 dusun Saman, Desa Bangunharjo, kecamatan Sewon, Kabupaten Bantul Kota Yogyakarta Provinsi Daerah Istimewa Yogyakarta

Adapun Letak daerah perbatasan secara langsung dengan Kopwan BMT An-Nisa' sebagai berikut

Sebelah Timur : Berbatasan dengan Jalan Parangtritis

Sebelah selatan : Berbatasan dengan Aqila

Sebelah Utara : Berbatasan dengan Rumah Makan Just In Cafe

Sebelah Barat : Berbatasan dengan dusun Saman 2.

Analisis

Akad

Dusun saman adalah termasuk dusun yang berpenduduk homogen dan termasuk dusun yang cukup maju dibandingkan dusun-dusun lain di Kecamatan Sewon, kemajuan tersebut tidak lepas dari beberapa faktor, salah satunya adalah letak Geografis yang sangat strategis dekat dengan perkotaan dan jalan Utama Ring Road, dengan demikian dapat memepengaruhi 
pola pikir masyarakatnya, sosial, budaya, dan status ekonomi, sedangkan mayoritas penduduk beragama Islam.Latar belakang terbentuknya Kopwan BMT An-Nisa' adalah berawal dari para pengurus pengajian An-Nisa' yang mempunyai keinginan kuat untuk berpartisipasi pada ranah ekonomi yang pada akhirnya nanti adalah demi terwujudnya kesejahteraan masyarakat pada umumnya, dan anggota pengajian pada khusunya, meskipun Kopwan BMT An-Nisa' baru resmi dibentuk pada tanggal 27 desember 2007, tapi sebenarnya pengajian An-Nisa' sudah memiliki lembaga keuangan mikro selama 6 tahun sebelumnya, selanjutnya para pengurus memsyawarahkan untuk mendirikan koperasi resmi dengan harapan lembaga keuangan organisasi dapat berkembang lebih maju dan besar, selanjutnya dibentuklah kepengurusan koperasi yang diketuai oleh ibu Isnaeni dan selanjutnya mendaftarkan secara resmi pada tanggal 21 April 2008 terbit akta pendirian : No. 051/BH/XV/2008 yang beralamat di jalan Parangtritis No 10 Km.3,4 Bangun Harjo Sewon Bantul

$\begin{array}{ll}\begin{array}{l}\text { Susunan perngurus KOPWAN BMT An-Nisa' } \\ \text { Dewan Pengawas Syari'ah }\end{array} & \begin{array}{l}: \text { I. Ibu. Dra. HJ. Muti'ah Asyhari Abta } \\ : \text { I Ibu Hj. Siti Aminah }\end{array} \\ \text { Dewan Pengawas } & \begin{array}{l}\text { : Ibu Nuning Sugiyati, SE } \\ \text { IIbu Dra. Hj Dwi Hening Jayati }\end{array} \\ \text { Pengurus: } & : \text { Ibu Isnaeni } \\ \text { Ketua } & : \text { Ibu Siti Khotijah Fajar } \\ \text { Wakil Ketua } & : \text { Ibu Komriatus Diniah } \\ \text { Sekertaris } & : \text { Ibu Hj. Badhi'atus Shaliah } \\ \text { Bendahara } & : \text { Ibu Hj. Shalihah Baskoro, SE } \\ \text { Wakil Bendahara } & \\ \text { Koordinator Kelompok: } & : \text { Ibu Rhodiyah } \\ \text { Krapyak Kulon } & : \text { Ibu Dachiriyah } \\ \text { Krapyak Wetan } & : \text { Ibu Hj. Titik Khomsatun } \\ \text { Krapyak Wetan } & : \text { saudari Watiyah } \\ \text { Janganan } & : \text { Ibu. Hj. Partilah } \\ \text { Sorowajan } & : \text { Ibu Siti Muhsiam } \\ \text { Saman } & : \text { Rini Susilowati } \\ \text { Pengelola } & : \text { Anis Fitri Rahayu } \\ & \end{array}$

\section{Gambaran Praktek Pembiayaan mudharabah pada Kopwan BMT An-Nisa'}

Pada praktek pembiayan mudhabah pada Kopwan BMT An-nisa' mengunakan sisitem bagi hasil Mudharib tersebut harus menjadi anggota koperasi Kopwan BMT An-Nisa'. Bisa dengan membuka tabungan di Kopwan BMT An-Nisa' dengan membayar sebesar Rp. 100.000 (seratus ribu rupiah) (Hasil wawancara dengan Ibu Rini Susilowati). Hal senada disampaikan pada Kopwan BMT An-Nisa' persyaratannya sangat mudah cukup FC KTP misalnya tidak ada menggunakan Kartu Kelurga terus mengisi fomulir/ langsung datang ke BMT An-Nisa', Tahapan ini dijelaskan bahwa pihak Kopwan BMT An-Nisa' akan menyediakan dana pembiayaan dalam bentuk uang kepada Mudharib dengan jumlah yang telah disepakati diawal kontrak. Namun nilai nominal pembiayaan di Kopwan BMT An-Nisa' untuk pembiayaan pertama kali yaitu sebesah Rp 500.000 (lima ratus ribu rupiah)( Hasil wawancara dengan Ibu Rini Susilowati). maka tahapan ini pembiayaan yang melakukan

Muhammad

Ngasifudin

Abdul Salam 68

JURNAL EKONOMI SYARIAH INDONESIA, Volume V, No.1 Juni 2015 
pelunasan setelahnya bisa mengambil pembiayaan selajutnya dengan jumlah meningkat. Penggunaan pembiayaan pertama kali adalah dengan jumlah Rp. 500.000 jika pantaun BMT An-Nisa' lancar maka bisa mengambil pinjaman lagi lebih dari yang awal karena untuk tahapan pertama memang nasabah tidak bisa mengambil lebih dari jumlah tersebut.(Hasil wawancara dengan Ibu Jariah

Pada perjanjian atua akad pembiayaaan Mudharabah yang dibuat oleh nasabah dan pihak BMT mengandung beberapa hal sebagai berikut:

Menerangkan Pihak-Pihak Yang Berakad.

Pada tahapan ini dijelaskan siapa pihak-pihak yang berakad yaitu Kopwan BMT-An-Nisa' sebagai shahibul mall dan nasabah sebagai Mudharib atau pengelola dana dan sebagai penerima pembiayaan Mudharabah.

Kedua belah pihak investor dan pengelola modal keduanya diisyaratkan memiliki kompetensi beraktivitas, yakni orang-orang yang tidak dalam kondisi bangkrut terlilit hutang, orang yang terlilit hutang, orang yang masih kecil, orang gila, orang ideot, semua tidak boleh melaksanakan transakasi ini dan bukan merupakan syarat bahwa salah satu pihak atau kedua belah pihak harus seorang muslim. Boleh saja bekerja sama dalam bisnis penanaman modal ini dengan orang-orang kafir ahlu dzimmah (orang-orang kafir yang dilindungi) atau orang-orang yahudi dan nasrani yang dapat dipercaya, dengan syarat harus terbukti adanya pemantauan terhadap aktivitas pengelolaan modal dari pihak muslim sehingga aktivitas tesebut terbebas dari riba dan bebagai bentuk jual beli yang berdasarkan riba.(Shawani \& al-Muslih: 2004)

Penjelasan tentang pihak-pihak yang menjalankan kontrak dan akad merupakan hal yang sangat penting dan menjadi salah satu unsur pokok dalam sebuah perjanjian pembiayaan Mudharabah yang mempunyai hubungan kepada klausa akad sesudah pembiayaan. Melalui penyebutan siapa yang akan mengikatkan diri dalam kontrak akan memberikan gambaran yang jelas terhadap tujuan dari pada pembiayaan Mudharabah yang diberikan

Menerangkan Pembiayaan dan Penggunaan Pembiayaan.

Modal adalah objek dari akad, dalam soal modal ini diisyaratkan harus merupakan alat tukar sepeti emas, perak atau uang secara umum, penanaman modal ini tidak boleh dilakukan dengan menggunakan barang, kecuali bila disepakati untuk menetapkan nilai harganya dengan uang, sehingga nilainya itulah yang menjadi modal yang digunakan untuk memulai usaha, dengan dasar itulah hitungan-hitungannya dianggap selesai untuk masa kemudian. (Shawani \& al-Muslih: 2004)

Tahapan ini dijelaskan bahwa pihak Kopwan BMT An-Nisa' akan menyediakan dana pembiayaan dalam bentuk uang kepada Mudharib dengan jumlah yang telah disepakati diawal kontrak. Namun nilai nominal pembiayaan di Kopwan BMT An-Nisa' untuk pembiayaan pertama kali yaitu sebesah Rp 500.000 (lima ratus ribu rupiah)(Hasil wawancara dengan Ibu Rini Susilowati) maka tahapan ini pembiayaan yang melakukan pelunasan setelahnya bisa mengambil pembiayaan selajutnya dengan jumlah meningkat.

Analisis

Akad Penggunaan pembiayaan pertama kali adalah dengan jumlah Rp. 500.000 jika pantaun BMT An-Nisa' lancar maka bisa mengambil pinjaman lagi lebih dari yang awal karena untuk tahapan pertama memang nasabah tidak bisa mengambil lebih dari jumlah tersebut.( Hasil wawancara dengan Ibu Rini Susilowati) 
Penyerahan uang dalam pembiayaan di Kopwan BMT An-nisa' dengan cara tunai langsung dan ada penjelesan tentang kegunanan pembiayaan Mudharabah.

Asal dari usaha dalam bidang bisnis bagi hasil (penanaman modal) adalah bidang perniagaan atau bidang-bidang terkait lainnya, diantaranya yang tidak termasuk perniagaan adalah bila pengelola modal mencari keuntungan melalui bidang perindustrian, bidang perindustrian tidak bisa dijadikan penanaman modal, karena itu adalah usaha karakter tertentu yang bisa disewakan. Kalau seseorang menanamkan modal untuk usaha itu maka penananman modal tidak sah, pengelola modal tidak boleh bekerjasama dalam penjualan barang-barang haram berdasarkan kesepakatan ulama, sepeti jual beli bangkai, darah, daging babi, minuman keras, dan jual beli riba sejenisnnya.(Shawani \& al-Muslih: 2004)

Menerangkan Jangka Waktu, Angsuran Dan Biaya Administrasi.

Didalam akad pembiayaan Mudharabah sebenarnya lama jangka waktu diserahkan penuh kepada nasabah/Mudharib, dimaksudkan dengan mengemban amanah tersebut apakah jangka waktu ini dapat diselesaikan dengan jangka waktu yang ditentukan oleh Mudharib.

Tidak ada salahnya membatasi waktu penanaman modal menurut pendapat ulama yang lebih rajih, sebagai mana pendapat yang dipilih oleh kalangan Hanafiyah dan Hanbaliyah dikiaskan dengan sistem penjaminan pada satu sisi, dan dengan berbagai kriteria lain yang dibolehkan, pada sisi lainya. Dalam kegiatan pembiayaan Mudharabah pada Kopwan BMT An-Nisa jangka waktu yang paling maksimal adalah 18 bulan.( Hasil wawancara dengan Ibu Rini Susilowati)

Realisasi akad pembiayan Mudharabah ini menggunakan asumsi angsuran seringan mungkin dan pembayarannya dapat dilakukan secara bertahap ataupun pembayaran dilakukan dibayarkan bagi hasilnya terlebih dahulu dan pokoknya dibayarkan selama beberapa bulan kemudian sesuai dengan diakad pembiayaan tersebut.

Dari setiap produk yang dihasilkan oleh Kopwan BMT An-Nisa', termasuk pembiayan bagi hasil tentu tidak terlepas dari proses transaksi yakni perjanjian. Dalam hal ini pembuatan perjanjian antara Kopwan BMT AnNisa' dan anggota (pengelola dana) pembiayaan bagi hasil. Dalam perjanjian tersebut pihak Kopwan BMT An-Nisa' benar-benar memperhatikan etika bisnis dalam Islam dengan menginginkan setiap pihak mendapatkan kepuasan dalam mengadakan transaksi. Oleh karena itu, mesti ada kerelaan antar pihak, dalam hal ini pihak Kopwan BMT An-Nisa' memberikan kesempatan kepada Mudharib untuk menyatakan ketidakpuasan dan keberatannya selama dalam perjanjian pembiayaan bagi hasil, terutama dalam masalah yang menyangkut jumlah pembiayaan, besarnya nisbah bagi hasil dan cara pengembaliannya. Dengan hal ini sehingga tidak mengakibatkan terjadinya kesalahpahaman diantara pihak Kopwan BMT An-Nisa' dan pengelola dana dikemudian hari.

Nasabah pembiayaan Mudharabah sepakat dengan besarnya biaya adaministrasi yang telah berlaku di Kopwan BMT An-Nisa' dengan besaran $1,5 \%$ dari pokok sebagai bahan biaya admistrasi. (Hasil wawancara dengan Ibu Rini Susilowati)

Muhammad

Ngasifudin

Abdul Salam

JURNAL EKONOMI SYARIAH INDONESIA, Volume V, No.1 Juni 2015 


\section{Menerangkan jaminan}

Anggunan atau jaminan pada dasarnya tidak dibolehkan dalam pembiayaan Mudharabah, karena pada prisipnya pembiayaan yang diberikan oleh pemilik modal shahibul mal adalah akad tabaru' dan ta'awun, namun karena uang yang digunakan oleh pihak Kopwan BMT An-Nisa' adalah uang yang dikumpulkan dari dana anggota dan dana pihak ke tiga maka demi kemaslahatan maka boleh menggunakan jaminan

Agunan atau jaminan ada agar nasabah tidak melakukan penyimpangan, selanjutnya demi menjaga kepercayaan yang diberikan kepada Kopwan BMT An-Nisa'. Namun di Kopwan BMT An-Nisa' pemberlakuan jaminan belum dapat dilaksanakan karena anggota dan Kopwan BMT An-Nisa' mempunyai tingkat kepercayaan yang tinggi satu dengan yang lain. Dengan pembiayaan berapapun jumlahnya di Kopwan BMT An-nisa' tidak ada jaminan sehingga tidak memberatkan nasabah Hasil (wawancara dengan Ibu Maryanti). Hal yang sama disampaikan Ibu Hidayati, Tukinah dan Nartini kegiatan pemiayaan mudharabah berbeda sekali dengan kegiatan pembiayaan yang berada di Bank pelecit atau yang lain yang terjelas adalah di BMT An-Nisa' tidak ada jaminan sekecil apapun dengan jumlah pinjaman yang tinggi sekalipun.

\section{Menenerangkan Tentang Ketentuan-Ketentuan Tambahan.}

Apabila terjadi wanprestasi diberlakukan bila nasabah melakukan cidera janji, yaitu tidak menepati janji dan kewajibannya terhadap bank dalam suatu perjanjian, dalam hukum Islam, seseorang diwajibkan untuk menghormati dan mematuhi setiap perjanjian atau amanah yang dipercayakan kepadanya (muhammad :2009).

Dalam perjanjian Mudharabah ini pihak Kopwan BMT An-Nisa' berhak menagih pembayaran dari nasabah dan ataupun siapapun yang memperoleh hak daripadanya atau sebagian atau seluruh jumlah kewajiban nasabah kepada Kopwan BMT An-Nisa' untuk dibayarkan dengan seketika atupun sekaligus. Apabila terjadi sengketa maka pihak Kopwan BMT An-Nisa' dan Mudharib menggunakan jalan musyawarah atau mufakat.

\section{Analisis Pembiayaan Mudharabah Prespektif Ekonomi Syari'ah}

Pada awal tahun 1999, Dewan syari'ah Nasional secara resmi didirikan sebagai lembaga syari'ah yang bertugas mengayomi dan mengawasi operasional aktivitas perekonomian Lembaga Keuangan Syari'ah (LKS). Selain itu juga untuk menampung berbagai masalah/ kasus yang memerlukan fatwa agar diperoleh kesamaan dalam penangganannya oleh masing-masing LKS (Himpunan Fatwa Dewan syari'ah, Edisi Kedua, (Jakarta:2003)

Secara umum pembiayaan Mudharabah di Kopwan BMT An-Nisa' terdiri dari beberapa unsur yaitu: Kopwan BMT An-nisa' bertindak sebagai shahibulmall secara penuh dan nasabah atau Mudharib sebagai pengelola usaha secara penuh; Kopwan BMT An-Nisa' tidak ikut serta dalam pengelolan usaha nasabah/Mudharib, Pembiayaan yang diberikan dan dinyatakan dalam

Analisis surat perjanjian atau akad dan sesuai jumlahnya dan berbentuk cash; Jangka waktu pembiayaan dan pelunasan pembiayaan sesuai dengan kesepakatan yang ada didalam akad; Pembagian keuntungan bagi hasil dinyatakan dalam presentase $60 \%$ untuk nasabah dan $40 \%$ untuk BMT atau menggunakan $70 \%$ Nasabah dan 30\% BMT; Sesuai dengan akad Mudharabah yang ada dalam 
fiqih Islam; Dalam hal pembiayaan Mudharabah pada Kopwan BMT An-Nisa' skema dalam pembiayaan Mudharabah maka peneliti menyajikan gambaran pembiayaan Mudharabah.

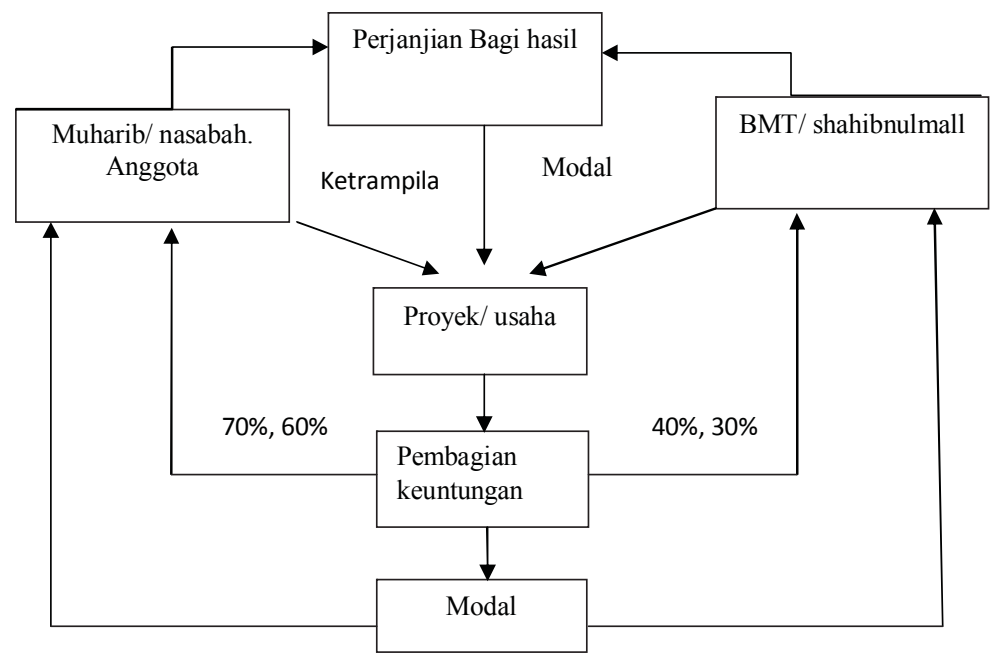

Bagan 2. Skema pembiayaan Mudharabah

Hadirnya perbangkan syariah dewasa ini menunjukan kecendrungan semakin baik, produk-produk yang ditawarkan juga mampu memberikan pilihan alternatif, dari survey yang pernah dilakukan, kebanyakan bank syariah masih mengedepankan produk jual beli, diantranya murobahah dan al-bai'u bithaman ajil. Padahal sebenarnya bank syari'ah memiliki produk unggulan, yang merupakan produk dari bank syariah. Produk tersebut adalah mudharabah dan musyarakah. (muhammad:2009)

Ada beberapa hal yang menyebabkan hal tersebut ditempuh oleh para pengelola bank syariah: Berkaitan dengan resiko bank yang ditimbulkan apabila menerapkan produk mudharabah adalah cukup tinggi dan tingkat kejujuran ke-amanah-an masyarakat kita yang belum $100 \%$ dapat diandalkan.

Berangkat dari dua alasan tersebut, maka dapat menimbulkan alasan pertama, fungsi bank syariah dalam hal ini adalah sebagai pihak yang memberikan informasi yang melakukan dakwah kepada masyarakat, berkaitan dengan cara yang terbaik bermuamalat dengan islam.

Imam Ahmad pernah ditanya tentang riba yang tidak diragukan lagi unsur ribanya, beliau menjawab " orang yang menghutangi seseorang, lalu ia berkata' anda mau melunasinya, atau mau menambahkan jumlahnya dengan dengan ditangguhkan lagi? kalau orang itu tidak segera melunasinya maka ia menanguhkan masa pembayarannya dengan menambambahkan jumlahnya" bentuk kedua : pinjaman dengan pembayaran tertunda, namun dengan syarat harus dibayar dengan bungannya. Hutang itu dibayar sekaligus pada saat berakhinya masa pembayaran Al-Jashshah menyatakan riba yang dikenal dan biasa dilakukan oleh masyarakat arab adalah bentuk pinjaman uang dirham atau dinar yang dibayar secara tunda dengan bunganya dengan jumlah sesuai dengan jumlah hutang dan sesuai dengan kesepakatan besama. Bentuk ketiga: pinjaman berjangka dan berbunga itu dengan syarat dibayar perbulan. Riba nasi'ah adalah kebiasaan yang sudah dikenal luas dan populer dimansa jahiliyah, yakni bahwa mereka biasa mengeluarkan uang agar mendapatkan jumlah uang tertentu pada setiap bulannya, sementara

Muhammad

Ngasifudin

Abdul Salam

72

JURNAL EKONOMI SYARIAH INDONESIA, Volume V, No.1 Juni 2015 
modalnya tetap. Apabila waktu pembayaran, maka meminta kepada orangorang yang berhutang untuk membayar jumlah modalnya. Kalau mereka tidak dapat melunasinya maka pembayaran diundur dengan mereka harus menambah jumlah yang harus di bayar, inilah riba yang dilakukan dimasa jahiliyah (muhammad: 2009).

Kegiatan pembiayaan mudharabah di Kopwan BMT An-Nisa' menyakup kegiatan yang menghidari dari unsur-unsur riba, pengembalian modal dan bagi hasil di BMT An-Nisa' biasanya bisa ditawar sesuai dengan kempunan keuangan dan keuntungan karena BMT An-nisa' berbeda dengan bankbank yang lain (Hasil wawancara dengan Ibu Heni K). Hal demikian juga disampikan dalam wawancara dengan ibu Chuswatun, Ibu Hesti, Ibu Narti.

\section{Terhindar dari Gharar (resiko)}

Larangan terhadap jual beli mengandung usur gharar alias menjual kucing dalam karung merupakan salah satu dasar syariat yang agung " Nabi melarang jual beli dengan sistem melempar krikil dan jual beli gharar (barang tidak jelas). Di riwayatkan oleh Muslim

Ditinjau dari hukum keharamnnya dan kehalalan, jual beli gharar menjadi tiga: pertama, bila kuantitasnya banyak, hukumnya dilarang berdasarkan ijma', seperti menjual ikan yang masih dalam air dan burung yang masih diudara. Kedua: bila jumlahnya sedikit, hukumnya dibolehkan menurut ijma, seperti pondasi rumah (dalam transaksi jual beli rumah), isi bagian dalam pakaian, dan sejenisnya. Ketiga: bila kualitasnya sedang-sedang saja, hukumnya masih diperdebatkan, namun parameter untuk mengetahui banyak sedikitnya kuantitas, dikembalikan kepada kebiasaan Shawani \& al-Muslih: 2004).

Bentuk-bentuk jual beli gharar:

Pertama: barang transaksi yang tidak ada dan tidak diyakini bisa didapatkan. Seperti jual beli tahunan, yakni menjual buah-buahan dalam perjanjian selama sekian tahun, buah-buahan tersebut belum ada, atau menjual buah yang belum tumbuh sempurna (belum layak dikonsumsi) letak usur gharar dalam penjualan buah-buahan belum layak konsumsi adalah bahwa buah-buahan itu masih dikhawatirkan terkena hama sehingga rusak. Itu adalah tindakan membuat kamuflase yang tidak dibutuhkan. Kalau malapetaka itu terajadi, berarti biaya yang dikeluarkan pembeli menjadi hilang tanpa ada imbalan, atau si pedagang mengambil keuntungan tidak dengan cara yang benar. Hal ini tentu saja dapat menimbulkan kebenciaan dan permusuhan.

Kedua: jual beli gharar yang tidak mungkin diserahkan terimakan. Seperti unta yang sedang kabur, ikan yang ada dalam air dan burung yang terbang tinggi di langit. Bentuk jualan ini ada yang dipastikan haram ada juga yang masih memperdebatkannya. Diantara yang masih diperdebatkan adalah menjual barang jualan sebelum berada ditangan, karena sangat dibutuhkan pengenalan terhadap hukum bentuk jual beli gharar yang terakhir ini, karena kaitannya yang erat dengan pengembangan sistem perbankan, kamipun sengaja mengkhususkan pengkajian untuk lebih mendalami perbedaan

Analisis pendapat para ulama fiqih dalam persoalan jual beli tersebut, kemudian Akad dalil yang digunakan oleh masing-masing kelompok, kemudian baru mempertimbangkan seluruh dalil-dalil itu untuk sampai kepada pendapat yang kita pilih dalam persoalan yang sudah mendarah daging tumbuh sebagai usaha pengembangan modal (investasi) 
Ketiga: menjual barang yang tidak diketahui, bisa jadi objek penjualan itu tidak diketahui secara mutlak, seperti bila seseorang penjual mengatakan, "saya jual sebuah mobil kepada anda", bisa juga sesuatu yang tidak diketahui namun tetentu jenis atau ukurannya, seperti yang dikatakan seorang penjual, saya jual kepada anda seluruh isi rumah saya. Atau sesuatu yang tidak diketahui dan tidak ada kriteria dan ketentuan apa-apa, seperti penjualan barang secara borongan, baik dengan jumlah tertentu atau juga dengan jumlah yang tidak diketahui.

\section{Terhindar dari Maysir (perjudian)}

Sebagaimana telah dikemukaakan Al-Qur'an mengutuk perjudian (maysir) dengan menyatakan bahwa dengan judi, setan, hanya ingin menyebarkan permusuhan dan kebencian diantara kamu dan menghalangi kamu dari mengingat Allah dan dari sembahyang. "Sunah tidak hanya membicarakan masalah perjudian tetapi resiko atau gharar. (Vogel dan Samuel:2007)

Rasullulah melarang jula-beli dengan batu krikil, (hasah, jual beli suatu barang yang dipilih atau ditentukan dengan melempar batu krikil) dan jual beli gharar (HR. Muslim) Spekulasi murni, hadist yang menggambarkan beberapa transaksi yang tampaknya merupakan perjudian disengaja, sebagai jual beli final terhadap nilai-nilai yang tidak diketahui sepenuhnya "hasil menyelam" atau lontaran batu apapun yang jatuh ketanah, transaksi yang juga masuk dalam kategori ini adalah transaksi samar pra islam yang lain yang dilarang oleh sunah. Yaitu transaksi yang, paling tidak berdasarkan satu pola penafsiran, tampak belum sempurna. Bentuk-bentuk perjudian menyenangkan dan digemari oleh pedagang: misalnya menjual barang apapun yang tengah kontrak pada masa pra islam ini selain namanya, dengan konsekuensi munculnya beragam penafsiran terhadap sifat dasarnya.

Berdasarkan paparan di atas hasil observasi dan wawancara dengan manager dan nasabah unsur-unsur yang harus dihindari dalam praktek pembiayaan atau Di Kopwan BMT An-nisa' tidak ditemukan hal tersebut, karena sebagian besar nasabah pembiayaan demi memenuhi kebutuhannya dengan Usaha Kecil Menengah, dan menghindari praktek yang demikian itu. anggota Kopwan BMT An-Nisa' mendapatkan kesempatan untuk megembangkan usaha dan memutarkan modalnya demi mendapatkan keuntungan. Pemahaman kegiatan pembiayaan di BMT An-nisa sesuai dengan syari'ah karena BMT An-Nisa' memang dengan tujuan untuk menolong sesame

\section{Dampak pembiayaan Mudharabah Terhadap Kesejahteraan (fallah)}

Sebagaimana Visi dan Misi Kopwan BMT An-Nisa' dengan visi mensejahteraakan anggotannya Kopwan BMT An-Nisa' salah satu lembaga keuangan syariah yang menjalankan akad pembiayaan mudharabah dengan tujuan untuk memberdayakan umat dan anggotanya agar menjadi lebih baik dari sebelumnya. Baik dari segi usahanya maupun dari segi pemahaman pola Ekonomi Syariah. Yang mana, yang menjadi sasaran pengembangan pada Kopwan BMT An-Nisa' ini adalah para pedagang-pedagang kecil yang membutuhkan modal agar dapat meningkatkan usahanya menjadi lebih baik berdasarkan prinsip syariah.

Pembiayaan mudharabah dalam peningkatan pendapatan dan kesejaheraaan anggotanya dapat sangat pengaruh tingkat pendapatan

Muhammad
Ngasifudin
Abdul Salam
74

JURNAL EKONOMI SYARIAH INDONESIA, Volume V, No.1 Juni 2015 
anggota Karena suatu pendapatan usaha tergantung dari besar kecilnya modal yang digunakan, Jika modal besar maka produk yang dihasilkan juga besar sehingga pendapatannya pun meningkat. Begitu juga sebaliknya jika modal yang digunakan kecil maka produk yang dihasilkan hanya sedikit dan pendapatan yang diperoleh juga sedikit. Untuk itu diperlukan pembiayaan dalam menjalankan suatu usaha guna meningkatkan usahanya, karena semakin banyak pendapatan yang dihasilkan maka secara otomatis kehidupan masyarakat pun akan tersejahterakan.

\section{Al-Ghina: Kerja Dan Kelayakan Hidup}

Beberapa ayat Al-Quran menyebutkan kata al ghina dengan maksud kekayaan dan kecukupan dalam hal harta atau rezeki.Pembiayaan yang dilakukan di BMT An-nisa sangat memberikan dampak yang positif terhadap pendapatan keluarga anggota dan kegiatan bagi hasilnya prinsip tolong menolong sesama anggota Hasil Wawancara dengan Ibu Nartini. Rata-rata pendapatan nasabah yang mempunyai Rp.1.111.111 (lihat lampiran). Dengan usaha yang dilakukan oleh anggota Kopwan BMT-An-Nisa' para anggota dapat merasakan dan menikmati hasil kerjanya dengan memenuhi kebutuhan kelurga, anggota Kopwan BMT An-Nisa' memanfaatkan kemampuanya untuk mempertahankan hidup.

\section{Al-'izz : Kemulian Dan Harga Diri}

Al Razi menyebutkan bahwa dalam pandangan Hasan bin Ali bin Abi Thalib dan kaum 'urafa, al-'izzah bukanlah kesombongan dan orang-orang mukmin tidak dihalalkan menghina diri sendiri (tidak percaya diri), 'izzah adalah memahami hakikat diri dan memuliakannya, kesombongan adalah kebodohan manusia tentang hakikat kedirinya dan posisi di Dunia.

Dari kegiatan yang dilakukan oleh para Anggota Kopwan BMT an-Nisa' termasuk mencari kemuliaan dan harga diri baik pribadi paupun keluarganya dengan membatu kebutuhan meringankan kebutuhan keluarga dan membatu suami dalam mencari nafkah tambahan, dengan kegiatan inilah rata-rata nasabah mempunyai kendaran bermotor dan bisa menyekolahkan anaknya sampai keluar SMA bahkan keluar provinsi.

Dari hasil observasi dan wawancara dengan para Anggota Kopwan BMT An-nisa dapat disimpulkan kegiatan yang dilakukan berdampak positif terhadap income tambahan keluarga di luar pendapatan suami, ini dapat dilihat dari banyak anggota yang mempunyai toko, warung, dll. Dengan demikian kegiatan usaha yang dilakukan anggota mampu memberikan dampak kesejahteraan (fallah) dari segi pendapatan maupun segi kemampuan financial keluarga.

\section{DAFTAR PUSTKA}

Agustina Fera, 2008, Skripsi Strategi Pemasaran Produk Mudharabah di BMT Bina Insanul Fikri Yogyakarta Yogyakarta: Fakultas Dakwah Universitas

Analisis Islam Negri Sunan Kalijaga.

Akad

75
Anshori, Abdul Ghofur, 2009, Perbankan Syari'ah Indonesia, Yogyakarta: Gadjah Mada University Press. 
Antonio, Muhammad Syafi'i, 1999, Bank Syari'ah Wacana Ulama dan Cendikiawan, Jakarta: Tazkia Institute.

2001, Bank Syari'ah Dari Teori Ke Praktek, Jakarta

:Gema Insani Press.

Anwar Syamsul, 2007, Hukum Perjanjian Syari'ah Jakarta : PT.Raja Grafindo Persada.

Arikunto Suharsimi,2002, Prosedur Penelitian Suatu Pendekatan Praktek, Jakarta: Rineka Cipta.

2010, Prosedur Penelitian Suatu Pendekatan Praktek, Jakarta: Rineka Cipta

Azwar Saefudin, 2005, Metode Penelitian, Yogyakarta: Pustaka Pelajar

Chalil Zaki Fuad, 2009, Pemerataan Distribusi Kekayaan Dalam Ekonomi Islam, Jakarta: Erlangga

Djazuli A. dan Janwari Yadi, 2002, Lembaga-Lembaga Perekonomian Umat, Jakarta.: PT Raja Grafindo.

Djuwaini Dimyauddin, 2008, Pengantar Fiqih Muamalah, Yogyakarta: pustaka pelajar

Dipoyudo Kirdi. 1995, Keadilan Sosial. TT: CV Rajawali.

Frank E. Vogel dan Samuel L hayes, III, 2007, Hukum Keuangan Islam Bandung : Nusamedia.

Haryono Amirul Hadi, 1995, Metodologi Penelitian Pendidikan, Bandung: Pustaka Setia

Himpunan Fatwa Dewan syari'ah, 2003, edisi kedua, Jakarta

Ikit, 2012, TesisAnalisis Pelaksanaan Sistem Pembiayaan Bagi Hasil Pada Bank Umum Syari'ah Di Daerah Istimewa Yogyakarta, Yogyakarta: Program Pascasarjana Hukum Islam Universitas Islam Negri Sunan Kalijaga

Karim, Adiwarman, 2004, Bank Islam Analisis Fiqih dan Keuangan, PT Raja Jakarta: Grafindo Persada.

Lessy Zulkipli, 2007, Model-Model Kesejahteraan Sosial Islam, (Yogyakarta : LKiS Pelangi Aksara

Mahfoedz Ircham, 2010, Metodelogi Penelitian, Yogyakarta: Penerbit Fitramaya.

Mahyudi Ahmad, 2004, Ekonomi Pembangunan dan Analisis Data Empiris. Bogor: Ghalila Indonesia.

Moleong Lexy J, 2011, Metodologi Penelitian Kualitatif, Edisi Revisi, Bandung: PT Remaja Rosda Karya. Rosda Karya 2007, Metodologi Penelitian Kualitatif. Bandung: PT Remaja

Mu'tamroh Laila, 2008, SkripsiFaktor- Faktor yang mempengaruhi Simpanan Mudharabah Pada Bank Syari'ah, Yogyakarta: Fakultas syari'ah, Universitas Islam Negri Sunankalijaga

Muhamad, 2000, Prinsip-prinsip Akuntansi Dalam Al-Quran, Yogyakarta: UII Press,

2004, Teknik Perhitungan Bagi Hasil dan Profit Margin Pada Bank Syari'ah, Yogyakarta: UII Press.

Muhammad

Ngasifudin

Abdul Salam

76

JURNAL EKONOMI SYARIAH INDONESIA, Volume V, No.1 Juni 2015 
2009, Model-Model Akad Pembiayaan di Bank Syari'ah, Yogyakarta:

UII Press.

2000, Sistem Dan Prosedur Operasional Bank Syari'ah, Yogyakarta: UII Press.

2005, Manajemen Bank Syari'ah, Ed. Revisi, Yogyakarta: UPP AMP YKPN.

Nawawi Ismail, 2009, Ekonomi Kelembagaan Syari'ah, Surabaya: Putra Media Nusantara

Rahman, Andy Fathur 2010 Tesis Analisis Faktor Yang Menyebabkan Terjadinya Moral Hazard Nasabah Pembiayan Mudharabah (Studi Penelitian di BTN Syari'ah Cabang Solo) Yogyakarta: Program Pascasarjana UIN Sunan Kalijaga

Rukminto, Isbandi Adi, 1994, Psikologi, Pekerjaan Sosial Dan Ilmu Kesejahteraan Sosial : Dasar-Dasar Pemikiran, Jakarta: Raja Grafindo Persada.

Rivai Veithzal dan Andria Permata, 2008, Islamic Financial Management, Jakarta: RajaGrafindo Persada,

M. Qurish Shihab, 2006, Wawasan Al-Quran, Bandung : Mizan

Sudarsono Heri, 2008, Bank Dan Lembaga Keuangan Syari'ah, Yogyakarta: Ekonosia

Sugiono, 2001, Metode Penelitian Administrasi, Bandung: Percetakan Alfabet 2009, Metode Penelitian Kuntitatif Kualitatif dan RED, Bandung: Alfabet.

Shalah Muhammad, 2008, Problematika Investasi Pada Bank Islam Solusi Ekonomi Islami, Jakarta : Nusantara Intikarya Pratama.

Shawani Shalah ash- dan Abdullah al-Muslih, 2004, Fikih Ekonomi Keuangn Islam, Jakarta : Darul Haq.

Suhendi Hendi, 2008, Fiqih Muamalah, Jakarta: PT Raja Grafindo Persada.

Sumantri Arif, 2011, Metodelogi Penelitian Kesehatan, Jakarta: Kencana Prenada Group.

Sumitro Warkum, 1997, Asas-Asas Perbankan Islam dan Lembaga-Lembaga Terkait (BAMUI dan Takaful) di Indonesia, Jakarta : PT Raja Grafindo Persada,

Supardi, 2005, Metodologi Penelitian Ekonomi dan Bisnis, Yogyakarta : UII Press.

Teguh Muhammad, 2005, Metodologi Penelitian Ekonomi, Jakarta: PT Raja Grafindo Persada

Mahyudi Ahmad, 2004, Ekonomi Pembangunan Dan Analisis Data Empiris. Bogor: Ghalila Indonesia.

Mustafa Ibrahim, tt, Mu'jam Wasith, Turki: Maktabah Islamiyah

Salam Abdul, 2010, TesisAnalisis Praktek Bagi Hasil Antara Juragan Dan Nelayan Dalam Perspektif Islam Yogyakarta : UGM pasca sarjana

Analisis

Akad

Rodin (2005) “Pandangan Masyarakat Pra Sejahtera Tentang Keluarga Sakinah (dikampung baru kel. Kota lama kec. Kedung kandang)", Skripsi, Malang: Fakultas Syari'ah. 
Departemen Agama RI, 2006, Al-Quran dan Terjemah, Jakarta : Quran Tajwid, Undang Undang No. 10 tahun 1998

Bank Indonesia, Outlook Perbankan Syari'ah Tahun 2013

Pusat Bahasa Departemen Pendidikan Nasional, 2002, Kamus Besar Bahasa Indonesia, Jakarta : Balai Pustaka

http://www.bkkbn-jatim.go.id

Muhammad

Ngasifudin

Abdul Salam

78

JURNAL EKONOMI SYARIAH INDONESIA, Volume V, No.1 Juni 2015 